\title{
PEMBERDAYAAN MASYARAKAT KELOMPOK USAHA BANDREK MELALUI PENAMBAHAN JAMBE SEBAGAI INOVASI DALAM MENINGKATKAN NILAI JUAL PRODUK
}

\author{
Benny Prawiranegara*, Eva Faridah \\ Fakultas Ekonomi Universitas Galuh \\ *Email: benny.feunigal@gmail.com
}

\begin{abstract}
ABSTRAK
Permasalahan utama mitra dalam kegiatan pengabdian masyarakat ini adalah sebagai berikut: 1) Masyarakat kurang mengenal produk bandrek jambe; 2) Minuman bandrek jambe tidak memiliki pasar yang luas; 3) Minuman bandrek jambe tidak memiliki strategi yang mampu memperluas pasar; 4) Minuman bandrek jambe tidak memiliki sisi inovasi yang mampu meningkatkan nilai jual produk. Tujuan kegiatan pengabdian masyarakat ini adalah untuk mengembangkan produk Bandrek Jambe dengan sebuah inovasi baru untuk dapat meningkatkan nilai jual prduk tersebut. Mitra dalam kegiatan pengabdian masyarakat ini adalah kelompok Bandrek Jambe yang melaksanakan kegiatan di dekat Rumah Sakit Umum Daerah (RSUD) Kabupaten Ciamis. Pelaksanaan dalam kegiatan pengabdian masyarakat ini adalah dilakukan dalam beberapa tahap sebagai berikut: 1) Tahap Inovasi Produk; 2) Tahap Pembuatan Label Produk; 3) Tahap Perhitungan Harga Pokok Penjualan; 4) Tahap Pembuatan dan Implementasi Startegi Pemasaran Produk; 5) Tahap Evaluasi; 6) Tahap Tindak Lanjut.
\end{abstract}

Kata kunci: pemberdayaan masyarakat, inovasi

\section{PENDAHULUAN}

Dalam persaingan usaha yang semakin kompetetif seperti sekarang ini, peran inovasi tampak semakin penting dan sangat menentukan untuk bisa memenangkan persaingan. Sari, Sasongko \& Wahyuni (2013) menyaakan bahwa dalam melaksanakan inovasi di era global pelaku bisnis perlu memusatkan perhatian pada konsumen, berusaha menciptakan nilai lebih dari harapan konsumen. Sementara itu, Fontana (2011) menyatakan bahwa inovasi merupakan suatu bentuk penunjang kesuksesan ekonomi, berkat adanya perkenalan cara baru atau kombinasi baru dari cara lama dalam mentransformasikan input menjadi output yang menciptakan perubahan besar dalam hubungan antara nilai guna dan harga yang di tawarkan kepada konsumen.

Berdasarkan pernyataan tersebut, maka dengan melakukan inovasi sebuah unit usaha atau perusahaan memiliki harapan untuk dapat menciptakan produk baru dan belum pernah ada sebelumnya atau membuat produk yang merupakan perbaikan dari produk yang sudah ada. Inovasi juga merupakan cara untuk meningkatkan nilai dan harga jula, namun perusahaan pun harus dapat menetapkan harga yang kompetitif agar konsumen tetap loyal.

Mitra dalam kegiatan pengabdian masyakat ini adalah kelompok Bandrek Jambe yang melakukan kegiatan di dekat Rumah Sakit Umum Daerah (RSUD) Kabupaten Ciamis. Produk bandrek jambe merupakan minuman khas yang berbahan dasar gula dan jahe dan sudah tidak asing lagi bagi para penikmat meinuman hangat tersebut di berbagai daerah. Bandrek yang dijual di tempat ini sebetulnya merupakan inovasi dari minuman tersebut, karena dicampur 
dengan biji jambe atau sering dikenal dengan biji buah pinang yang digiling halus secara tradisional.

Biji jambe tersebut dipercaya memiliki berbagai macam khasiat bagi tubuh manusia, seperti mengatasi mulut kering, menguatkan gigi dan busi, obat cacing, mengobati kulit yang luka, rabun mata, mengencangkan alat vital kewanitaan dan bahkan dapat meningkatkan vitalitas. Untuk menambah khasiat, minuman bandrek jambe tersebut dapat dicampur dengan kuning telor bebek, tergantung dari permintaan dari si pembeli. Minuman bandrek jambe banyak diminati, khususnya bagi masyarakat Ciamis, dimana penjual minuman tersebut buka setiap harinya dari mulai sore hari hingga malam hari, sampai minuman tersebut habis dibeli oleh pelanggan.

Karena dipercaya dan santer dapat meningkatkan vitalitas, maka permasalahan yang terjadi adalah peminat bandrek jambe tersebut hanya didominasi oleh kaum pria dewasa saja. Padahal banyak khasiat dari biji jambe tersebut bagi berbagai kalangan, bukan hanya untuk meningkatkan vitalitas saja. Jika produk tersebut dikembangkan dengan sebuah inovasi, maka tidak menutup kemungkinan produk bandrek jambe akan banyak dimintai semua kalangan dan dapat dipasarkan secara luas.

Berdasarkan analisis situasi tersebut, maka tujuan dari kegiatan pengabdian masyarakat ini adalah untuk mengembangkan produk Bandrek Jambe dengan sebuah inovasi baru untuk dapat meningkatkan nilai jual prduk tersebut. Mitra dalam kegiatan pengabdian masyarakat ini adalah kelompok Bandrek Jambe. yang direncanakan adalah produk yang inovatif dan memiliki nilai jual tinggi. Secara spesifik, tujuan kegiatan ini adalah: (1) Meningkatkan nilai produk dengan inovasi menambahkan biji jambe pada minuman bandrek serta inovasi kemasan sehingga memiliki nilai lebih yang diharapkan oleh masyarakat/konsumen, (2) Meningkatkan pendapatan bagi kelompok usaha, dan (3) Melakukan pendampingan usaha.

\section{BAHAN DAN METODE}

Permasalahan utama mitra dalam kegiatan pengabdian masyarakat ini adalah sebagai berikut: 1) Peminat bandrek jambe hanya didominasi oleh kaum pria dewasa; 2) Minuman bandrek jambe tidak memiliki pasar yang luas; 3) Minuman bandrek jambe tidak memiliki sisi inovasi yang mampu memperluas pasar; 4) Minuman bandrek jambe tidak memiliki sisi inovasi yang mampu meningkatkan nilai jual produk.

Solusi yang ditawarkan untuk memecahkan permasalahan mitra adalah dengan membuat inovasi produk untuk meningkatkan nilai jual produk bandrek jambe. Inovasi yang ditawarkan adalah menjadikan produk bandrek jamber menjadi minuman kemasan 
menggunakan gelas plastik ukuran $240 \mathrm{ml}$. Dengan merubah bentuk kemasan tersebut, tidak menutup kemungkinan produk minuman bandrek jamber akan banyak diminati oleh berbagai kalangan serta dapat dipasarkan secara luas, karena dipercaya memiliki banyak khasiat.

Solusi lain yang ditawarkan adalah pembuatan lebel produk (brand image), perhitungan harga pokok penjualan produk dan strategi pemasaran. Menurut Prawoto, Susilawati, \& Faqih (2018) melalui hasil program pengabdiannya menjelaskan bahwa inovasi yang dilakukan terhadap produk makanan berbahan dasar ikan lele dapat meningkatkan nilai jual produk tersebut. Hasil penelitian yang dilakukan oleh Putra \& Ekawati (2017) menunjukan bahwa inovasi produk dapat meningkatkan loyalitas pelanggan. Berdasarkan penjelasan tersebut, maka dapat disimpulkan bahwa solusi yang ditawarkan dalam kegiatan pengabdian masyarakat kepada mitra ini merupakan jawaban atas permasalahan-permasalahan yang dihadapi oleh mitra itu sendiri, dengan tahapan sebagai berikut:

1. Tahap Inovasi Produk

Pada tahap ini adalah kegiatan untuk meningkatakan kreativitas mitra dalam mengubah produk bandrek jambe yang awalnya adalah minuman yang diolah dan langsung diminum menjadi produk minuman kemasan dalam gelas plastik ukuran $240 \mathrm{ml}$. Metode yang digunakan adalah metode pelatihan dengan cara demonstrasi untuk memberikan contoh penggunaan teknologi kemasan.

2. Tahap Pembuatan Label Produk

Pada tahap ini dimulai dengan penentuan nama label produk (brand image) yang dilanjutkan dengan tahap kegiatan untuk meningkatkan keterampilan mitra dalam menggunakan teknologi pembuatan label produk. Tahap penentuan brand image dilakukan dengan metode diskusi untuk menentukan nama yang cocok dan menarik untuk dijadikan brand image produk tersebut, dimana disukusi dilakukan bersama-sama antara Tim pengabdian masyarakat dengan mitra. Sedangkan tahap pembuatan label adalah dengan menggunakan metode demonstrasi untuk memberikan contoh penggunaan teknologi pembuatan label produk.

3. Tahap Perhitungan Harga Pokok Penjualan Produk

Pada tahap ini adalah kegiatan untuk menghitung Harga Pokok Penjualan Produk (HPP) dari produk kemasan bandrek jambe. Metode yang digunakan pada tahap ini adalah metode disukusi yang dilakukan oleh Tim pengabdian masyarakat untuk mengitung secara bersama terkait dengan biaya-biaya yang dikeluarkan untuk menghasilkan produk bandrek jambe kemasan, dari mulai biaya bahan baku hingga biaya pemasaran.

4. Tahap Pembuatan Startegi dan Implementasi Pemasaran Produk 
Pada tahap ini dimulai dengan kegiatan untuk menentukan strategi yang cocok diterapkan untuk memasarkan produk bandrek jambe kemasan baik strategi pemasaran secara konvensional maupun secara digital. Kegiatan berikutnya adalah tahap implementasi pemasaran produk dengan cara membantu mitra dalam memasarkan produk bandrek jambe kemasan. Tahap pembuatan strategi pemasaran produk dilakukan dengan metode diskusi untuk menentukan strategi apa yang cocok diterapkan bagi pemasaran produk tersebut. Sementara itu tahap implementasi pemasaran produk dilakukan dengan metode pendampingan, dengan tujuan untuk mendampingi mitra dalam melaksanakan pemasaran produknya.

5. Tahap Evaluasi

Pada tahap ini dilakukan evaluasi terhadap semua tahapan kegiatan yang sudah dilaksanakan bersama mitra, sehingga dapat diketahui sejauh mana kemajuan usaha mitra, serta mengetahui permasalahan-permasalahan atau kendala-kendala yang dihadapi dalam kemajuan usaha mitra. Berdasarkan hal tersebut, maka dapat diberikan solusi untuk perbaikan-perbaikan ke depan terkait dengan usaha mitra.

6. Tahap Tindaklanjut

Pada tahap ini adalah untuk menindaklanjuti kerjasama dengan mitra, dalam rangka untuk memonitor dan mebantu mitra dalam mengembangkan usahanya setelah kegiatan pengabdian masyarakat ini berakhir. Rencana yang akan dilakukan adalah menjadikan usaha mitra sebagai UMKM binaan Fakultas Ekonomi Universitas Galuh Ciamis.

\section{HASIL DAN PEMBAHASAN}

\section{Evaluasi Awal}

Dari hasil diskusi dalam forum Focus Group Discussion (FGD) diperoleh beberapa beberapa informasi mengenai rendahnya pengetahuan mitra mengenai pembuatan inovasi produk, pengelolaan usaha, pemasaran produk, dan peningkatan produksi.

\section{Pelatihan inovasi diferensiasi produk}

Kegiatan pelatihan dilakukan pada hari Sabtu tanggal 06 Maret 2019 dari mulai pukul 08.00 WIB sampai dengan pukul 12.00 WIB. Pelatihan ini dilakukan dengan tujuan untuk memberikan pengetahuan serta meningkatkan keterampilan mitra dalam inovasi produk. Kegiatan pelatihan dilakukan dengan metode demonstrasi. Metode ini dipilih untuk menyampaikan tahapan-tahapan serta cara-cara inovasi produk bandrek. 
Pelatihan ini berupa pembuatan bandrek jambe dengan penambahan berbagai variasi rasa yang dapat diaplikasikan kepada produk bandrek jambe. Setelah diberikan pelatihan pembuatan bandrek jambe varian rasa, peserta telah mengalami perubahan dalam pembuatan produk tersebut. Para peserta dapat berinovasi dalam mengkreasikan produk, salah satunya adalah bandrek jambe dengan rasa melon. Sehingga produk yang dihasilkan dapat menjadi produk andalan dan khas di Kabupaten Ciamis.

Materi pelatihan yang diberikan adalah seputar pengenalan dan pembuatan bandrek jambe dengan berbagai tambahan rasa. Dari contoh tersebut para peserta dapat mengkreasikannya dengan bumbu-bumbu yang lain, seperti bumbu matcha, keju dan lainnya, karena cara pembuatannya tidak terlalu berbeda, hanya berbeda dari bumbu saja. Pada pelaksanaan pelatihan ini tim pelaksana tidak mengalami kesulitan yang berarti, pengalaman dan naluri peserta yang merupakan kaum perempuan dalam membuat suatu produk makanan sangat membantu kami dalam proses kegiatan ini.

\section{Pelatihan Manajemen Usaha Kecil}

Pelatihan manajemen usaha kecil dilakukan pada hari yang sama dengan pelatihan pembuatan keripik varian rasa, yaitu pada hari minggu tanggal 15 Maret 2019 pada pukul 13.00 WIB sampai dengan pukul 15.00 WIB. Kegiatan pelatihan ini menggunakan metode ceramah dan demonstrasi, dimana materi-materi yang diberikan kepada kedua mitra diseusaikan dengan kebutuhan peserta dan pengetahuan peserta untuk memahami konsep penting mengenai pengelolaan usaha kecil dalam rangka meningkatkan perekonomian keluarganya, sehingga materi yang diberikan dapat menjembatani peserta untuk dapat mengelola usahanya dalam memasarkan produk bandrek jambe varian rasa.

Materi pengelolaan usaha kecil yang diberikan kepada peserta meliputi: (1) Motivasi berwirausaha, (2) Pengelolaan manajemen usaha kecil, (2) Pengelolaan permodalan usaha kecil, (3) Manajemen sumber daya manusia (MSDM), dan (4) Pengelolaan produksi usaha kecil.

Sesi terkahir dalam pelatihan manajemen usaha kecil para peserta diberikan waktu untuk bertanya terkait dengan materi yang diberikan. Secara umum dari beberapa peserta bertanya mengenai keingintahuan mereka mengenai pemasaran produk yang nantinya akan mereka pasarkan. Pemasaran merupakan kegiatan yang sangat diutamakan, karena menyangkut kuantitas dari penjualan produk mereka nantinya. Dengan adanya pelatihan ini terlihat ada perkembangan dari motivasi serta pemahaman mereka tentang pengelolaan usaha kecil. 
Pemberdayaan Masyarakat Kelompok Usaha Bandrek Melalui Penambahan Jambe Sebagai Inovasi Dalam Meningkatkan Nilai Jual Produk Benny Prawiranegara, Eva Faridah

\section{Pendampingan Usaha}

Pada tahap awal melakukan kegiatan usahanya, para peserta melakukan kegiatannya berdasarkan pesanan. Pada tahap ini kami membantu mempromosikan produk bandrek jambe varian rasa yang mereka buat. Kegiatan pendampingan usaha ini bertujuan untuk memberikan pendampingan bagaimana mengelola usaha kecil dari awal pendirian usaha peserta sehingga usaha yang dirintis oleh para peserta dapat maju dan berkembang dan dapat dijadikan sarana untuk memperbaiki perekonomiannya.

Dalam pendampingan usaha ini diberikan pemahaman mengenai hal-hal berikut ini: (1) Bagaimana mengelola permodalan usaha kecil, (2) Bagaimana mengelola keuangan usaha kecil, (3) Bagaimana pemasaran usaha kecil, dan (4) Bagaimana melakukan pengemasan produk sederhana untuk usaha kecil.

\section{Evaluasi Akhir}

Evaluasi akhir dalam kegiatan ini dilakukan dengan melakukan kunjungan ke tempat usaha peserta dengan tujuan untuk mengetahui tingkat pemahaman peserta dalam memahami materi-materi yang telah diberikan selama kegiatan berlangsung serta untuk mengetahui keterampilan peserta dalam membuat produk bandrek jambe varian rasa dan menjalankan usahanya. Berdasarkan hasil evaluasi yang dilakukan, para peserta dalam kegiatan ini mengalami perkembangan yang positif mengenai pemahaman terhadap materi-materi yang diberikan, sehingga mereka mulai melaksanakan usahanya sesuai arahan (Tabel 1).

Tabel 1. Target dan Realisasi Hasil Kegiatan

\begin{tabular}{|c|c|c|c|}
\hline \multirow{2}{*}{ Kegiatan } & \multicolumn{2}{|c|}{ Indikator Kinerja } & \multirow{2}{*}{ Keterangan } \\
\hline & Target & Realisasi & \\
\hline $\begin{array}{l}\text { Evaluasi awal untuk } \\
\text { mengetahui potensi yang } \\
\text { dimiliki mitra serta } \\
\text { kendala-kendala yang } \\
\text { dihadapi mitra dalam } \\
\text { usaha }\end{array}$ & $\begin{array}{l}\text { Diketahuinya informasi } \\
\text { mengenai potensi masyarakat } \\
\text { serta kendala yang dihadapi } \\
\text { oleh mitra dalam } \\
\text { menjalankan usahanya }(90 \%)\end{array}$ & $\begin{array}{l}\text { Dihasilkannya strategi atau } \\
\text { upaya-upaya dalam } \\
\text { menghadapi permasalahan } \\
\text { mitra dalam menjalankan } \\
\text { usahanya }(100 \%)\end{array}$ & \\
\hline $\begin{array}{l}\text { Pelatihan pembuatan } \\
\text { bandrek jambe dengan } \\
\text { varian rasa }\end{array}$ & $\begin{array}{l}\text { Tingkat pemahaman dan } \\
\text { keterampilan mitra dalam } \\
\text { pembuatan bandrek jambe } \\
\text { berbagai rasa }(80 \%)\end{array}$ & $\begin{array}{l}\text { Tingkat pemahaman dan } \\
\text { keterampilan mitra dalam } \\
\text { pembuatan bandrek jambe } \\
\text { berabgai ras }(100 \%)\end{array}$ & $\begin{array}{l}\text { Dihasilkannya produk } \\
\text { inovatif dan bernilai } \\
\text { jual tinggi }\end{array}$ \\
\hline $\begin{array}{l}\text { Pelatihan manajemen } \\
\text { usaha kecil }\end{array}$ & $\begin{array}{l}\text { Tingkat pemahaman dan } \\
\text { keterampilan mitra mengenai } \\
\text { manajemen usaha kecil } \\
(80 \%)\end{array}$ & $\begin{array}{l}\text { Tingkat pemahaman dan } \\
\text { keterampilan mitra mengenai } \\
\text { manajemen usaha kecil } \\
(85 \%)\end{array}$ & $\begin{array}{l}\text { Modul Manajemen } \\
\text { Usaha Kecil }\end{array}$ \\
\hline $\begin{array}{l}\text { Pendampingan } \\
\text { usaha } \\
\text { Evaluasi akhir untuk } \\
\text { mengetahui keberlanjutan } \\
\text { kelompok }\end{array}$ & $\begin{array}{l}\text { Keterampilan mitra dalam } \\
\text { menjalankan usaha }(80 \%) \\
\text { Kemajuan kelompok usaha } \\
(70 \%)\end{array}$ & $\begin{array}{l}\text { Keterampilan mitra dalam } \\
\text { menjalankan usaha }(85 \%) \\
\text { Kemajuan kelompok usaha } \\
(75 \%)\end{array}$ & $\begin{array}{l}\text { Jasa Pendampingan } \\
\text { Usaha }\end{array}$ \\
\hline
\end{tabular}


Kendala yang dihadapi dalam kegiatan ini adalah, kurangnya komitmen dari pihakpihak terkait untuk mengembangkan program kelompok usaha ini. Tidak adanya tenaga pendamping dari kecamatan yang berasal dari Tenaga Kesejahteraan Sosial Kecamatan (TKSK), dimana hal tersebut merupakan suatu kendala untuk mengembangkan kelompok usaha dikemudian hari. Adanya tenaga pendamping dari TKSK merupakan salah satu syarat agar kelompok usaha yang telah dibentuk dan dibangun dapat memperoleh bantuan permodalan dari Kementerian Sosial melalui Bantuan Langsung Pemberdayaan Sosial (BLPS).

\section{Pemantauan Khusus Untuk Keberlanjutan}

Kegiatan ini dilakukan untuk memantau perkembangan kegiatan peserta setelah selesainya kegiatan ini. Kegiatan pemantauan ini adalah untuk mengetahui motivasi peserta untuk terus berwirausaha. Hasil yang diperoleh adalah menurunnya motivasi sebagian peserta, sebanyak $80 \%$ peserta masih mempunyai keinginan yang besar untuk terus beriwirausaha, sedangkan sisanya sebanyak $20 \%$ peserta mulai mengalami penurunan motivasi untuk terus berwirausaha pasca selesainya kegiatan ini.

Kondisi tersebut disebabkan karena sebagian peserta memiliki motivasi hanya pada saat kegiatan berlangsung, selebihnya mereka berfikir setelah selesai kegiatan tidak ada tindaklanjut untuk kedepan. Sebagian peserta masih belum dapat berfikir mandiri, sehingga mereka terkesan harus terus mendapatkan pendampingan. Keberlanjutan kelompok usaha ini selayaknya harus terus mendapatkan perhatian khusus dari pihak-pihak terkait, terutama dari pihak Pemerintahan untuk terus membantu mereka dalam menjalankan usahanya, sehingga kelompok usaha ini dapat diperkuat dari segi permodalan.

\section{KESIMPULAN DAN SARAN}

\section{Kesimpulan}

Berikut adalah beberapa kesimpulan dalam kegiatan kegiatan pengabdian kepada masyarakat (PKM), yaitu:

1. Terciptanya produk yang inovatif dan bernilai jual tinggi, yaitu produk bandrek jambe varian rasa di Kabupaten Ciamis.

2. Pelatihan manajemen usaha kecil dengan memberikan pemahaman mengenai bagaimana mengelola dan mengembangkan usaha kecil. 
3. Melakukan pendampingan usaha kepada mitra, agar mitra paham dalam implementasi menjalankan usaha kecil kelompok.

4. Hasil evaluasi akhir menunjukan sebanyak $80 \%$ peserta masih memiliki motivasi untuk terus berwirausaha, sedangkan sisanya sebanyak $20 \%$ terjadi penurunan motivasi.

\section{Saran}

1. Kelompok sasaran kegiatan

a. Sebaiknya melakukan studi banding dengan beberapa kelompok yang telah berhasil dari segi usahanya dan dari segi pengelolaan keuangan usahanya, sehingga hal tersebut dapat dijadikan dasar dalam pengembangan kelompok.

b. Sebaiknya banyak berkonsultasi dengan para akademisi ataupun kepada mahasiswa yang ada di sekitarnya terkait dengan pengelolaan usaha kecil.

2. LPPM Universitas Galuh menindaklanjuti program ini dengan melibatkan dosen ahli, karena mitra masih memerlukan pendampingan untuk dapat menjankan usaha kecilnya.

3. Pihak pemerintah hendaknya melakukan pendampingan kepada kelompok usaha yang berada di daerahnya, karena salah satu indikator peningkatan perekonomian masyarakat adalah melalui pengembangan UMKM.

\section{DAFTAR PUSTAKA}

Sari, A. Y., Sasongko, \& Wahyuni, S. (2013). Inovasi Produk Dalam Meningkatkan Minat Beli Konsumen Pada Pia Warung Glenmore Banywangi. Fisip: Universitas Jember, 6.

Fontana, A. (2011). Inovate We Can. Jakarta: PT. Gramedia.

Prawoto, E., Susilawati, H., \& Faqih, N. (2018). Strategi Inovasi Produk Olahan dan Manajemen Pemasaran Guna Meningkatkan Daya Jual Lele (UKM Peternak Lele di Desa Kalibeber, Mojotengah, Wonosobo). PPKM I, 123-127.

Putra, M. C. S. D., \& Ekawati, N. W. (2017). Pengaruh Inovasi Produk, Harga, Citra Merek dan Kualitas Pelayanan terhadap Loyalitas pelanggan Sepeda Motor Vespa. E-Jurnal Manajemen Unud, 6(3), 1674-1700.

Ellitan, L \& Anatan, L. (2009). Manajemen Inovasi. Bandung: Alfabeta.

Kotler, P. (2009). Manajemen Pemasaran, Edisi 13. Jakarta: Erlangga.

Schiffman, L.G., \& Kanuk, L.L. (2010). Consumer Behavior Tenth Edition. Pearson Education.

Kotler, P \& Armstrong, G. (2008). Prinsip-Prinsip Pemasaran, Jilid 1. Erlangga: Jakarta.

David, F.R (2011). Strategic Management, Buku 1. Edisi 12 Jakarta.

Prakosa,B. 2005. Pengaruh Orientasi Pasar, Inovasi dan Orientasi Pembelajaran Terhadap Kinerja Perusahaan Untuk Mencapai Keunggulan Bersaing (Studi Empiris Pada Industri Manufaktur di Semarang), Jurnal Studi Manajemen dan Organisasi, Vol.2, No.1.

Prasetya,D.I. 2002. Lingkungan Eksternal, Faktor Internal, dan Orientasi Pasar Pengaruhnya Terhadap Kinerja Pemasaran, Jurnal Sains Pemasaran Indonesia, ISSN 1412-8527, Vol.1, No.3.

Saiman, L. 2014. Kewirausahaan (Teori, Praktik, dan Kasus-kasus), edisi kedua. Salemba 
Empat, Jakarta.

Sismanto,A. 2006. Analisis Pengaruh Orientasi Pembelajaran, Orientasi Pasar dan Inovasi Terhadap Keunggulan Bersaing Untuk Meningkatkan Kinerja Pemasaran. Fakultas Ekonomi Universitas Diponegoro. Tesis Undip. Semarang.

Stanton,W.J. 2000. Prinsip Pemasaran, edisi ketujuh, Erlangga, Jakarta.

Supranoto, M. 2009. Strategi Menciptakan Keunggulan Bersaing Produk Melalui Orientasi Pasar, Inovasi, dan Orientasi Kewirausahaan Dalam Rangka Meningkatkan Kinerja Pemasaran. Fakultas Ekonomi Universitas Diponegoro. E-journal Undip. 